\title{
Comparison of Coherence and Efficiency in Discourse Production of Middle-old and Old-old Elderly
}

\author{
Bo Seon Kim', Mi Sook Lee ${ }^{2}$ \\ 'Department of Psychiatry, Incheon ST. Mary's Hospital, The Catholic University of Korea, Incheon, Korea \\ ${ }^{2}$ Department of Audiology \& Speech-Language Pathology, Hallym University of Graduate Studies, Seoul, Korea
}

\section{중고령층과 초고령층 담화 산출의 통일성과 효율성 비교}

김 보 선 $^{1} \cdot$ 이 미 숙 ${ }^{2}$

가톨릭대학교 인천성모병원 정신건강의학과', 한림국제대학원대학교 청각언어치료학과 ${ }^{2}$

\begin{abstract}
Purpose: The purpose of this study was to compare the degree of coherence and efficiency in the discourse production of cognitively healthy middle-old and old-old groups in elderly. Methods: Eleven middle-old (age: $79.00 \pm 2.76$ ) and 6 old-old subjects (age: $89.67 \pm 3.78$ ) performed three types of discourse tasks. The coherence score and the propositional density were used to compare the degree of topic maintenance and efficiency between two groups. The differences between the groups were assessed using the Mann-Whitney $\mathrm{U}$ test. A correlation among the two scores, demographic information, language test results, and the Korean version of the Mini-Mental State Examination (K-MMSE) were also examined. Results: There was a significant difference in propositional density between the two groups. The coherence score correlated with age, K-MMSE, and a confrontation naming test. Conclusion: The results of the present study is significant in that it is the first study to compare the performance of discourse production in the old-old elderly with those of the middle-old elderly. In addition, theme maintenance of normal elderly over 75 years of age is associated with their confrontation naming abilities and overall cognitive abilities.
\end{abstract}

Key Words: Discourse, Aging, Coherence, Propositional analysis, Language ability.

Received: September 19, 2018 / Revised: October 7, 2018 / Accepted: October 15, 2018

Correspondence: Mi Sook Lee, Department of Audiology \& Speech-Language Pathology, Hallym University of Graduate Studies, 405 Yeoksam-ro, Gangnam-gu, Seoul 06198, Korea

Tel: +82-2-3453-9333 / Fax: +82-2-3453-6618 / E-mail: mslee2018@hallym.ac.kr

\section{INTRODUCTION}

노화에 따른 담화 산출의 변화는 주제 유지의 어려움, 즉 장 황함(verbosity)의 증가(Arbuckle \& Gold, 1993; Arbuckle et al., 2004; James et al., 1998; Ruffman et al., 2010; Trunk \& Abrams, 2009)와 효율성(efficiency)의 저하(Mackenzie, 2000; Marini et al., 2005)로 보고된다. 노년층 담화 산출의 장황함은 발화단위 또는 전체 담화의 장황함 정도를 주관적으로 평가하 는 평정척도(rating scales), 또는 주제에서 벗어난 단어나 문장

(c) This is an Open Access article distributed under the terms of the Creative Commons Attribution Non-Commercial License (https://creativecommons.org/licenses/by-nc/4.0) which permits unrestricted non-commercial use, distribution, and reproduction in any medium, provided the original work is properly cited.
이 전체 담화에서 차지하는 비율로 평가되었다. 노화에 따른 주제에서 벗어난 발화의 증가는 다음의 세 가지 이유로 설명된 다. 첫째, 담화를 산출하는 동안 사전적 지식에의 접근 과정 및 발화를 위한 통사론적 계획을 하는 데 기능적으로 어려움을 보 이게 되는 언어 특이적인 손상(language specific impairment) 이 이 같은 주제에서 벗어난 발화를 만들어낸다(Mortensen et al., 2006). 둘째, 발화를 산출하는 동안 작업기억에서 불필요한 정보를 억제하지 못한다는 보다 일반적인 인지적 손상, 즉 억제 결함 모델(the inhibitory deficit model)도 장황한 발화에 기여 한다(Arbuckle \& Gold, 1993; James et al., 1998). 억제결함 모 델에 따르면, 불필요한 정보를 억제하는 능력은 나이가 듦에 따라 감소되며, 일단 불필요한 정보가 활성화되면 더 많은 불 
필요한 정보가 활성화되면서 이러한 정보를 억제하는 데 그 효 율성이 떨어지게 된다(Arbuckle \& Gold, 1993). 셋째, 노년층 은 젊은 사람들과 비교하여, 그들의 발화 목적이 객관적이고 주제에 일관되기보다는 개인적인 내러티브, 회상담(reminiscence), 자신의 정체성(identity)를 견고하게 하는 데 더 주력한 다는 화용론적 변화 가설(the pragmatic change hypothesis) 이 주제에 일관적이지 않은 노년층 담화 산출을 설명한다 (James et al., 1998). 이러한 노년층 발화의 주제 유지 정도를 측정하기 위해, 0 9점(Arbuckle \& Gold, 1993; Arbuckle et al., 2004), 또는 1 7점 척도(Trunk \& Abrams, 2009)를 이용하 거나, 주제에서 벗어난 발화의 시간(Ruffman et al., 2010)이나 양(Arbuckle et al., 2004)을 측정했다. 그러나 주제에서 벗어난 발화에 대한 판단은 발화를 이끌어내는 과제의 종류 및 장황함 의 정도를 평정하는 채점자의 영향을 받는다(Trunk \& Abrams, 2009).

정상 노년층이 직접 산출한 담화를 분석한 대부분의 실험연 구들에 의하면, 담화의 효율성은 보다 다양한 방법으로 측정되 어 왔는데 그중에서 내용 단위(content units, CU) (Yorkston \& Beukelman, 1980)와 올바른 정보단위(correct information units, CIU) (Nicholas \& Brookshire, 1993)가 대표적 측정법 이다. CU와 CIU를 분석한 연구들에 따르면, 발화의 효율성은 65세를 기점으로는 유지되나(Kwon et al., 1998; Lee \& Kim, 2001), 젊은 층에 비해 75세를 기점으로 감소된다(Mackenzie, 2000; Marini et al., 2005). 즉, 정상 노년층의 담화 수행은 노 화에 따라 효율성이 떨어지며, 정보를 전달하는 데 더 오랜 시 간이 걸리거나, 더 많은 발화를 필요로 한다(Marini et al., 2005). 한편, 장황함에 대한 연구는 70 대의 정상 노년층을 20 대 의 젊은 층과 비교하여, 젊은 층에 비해 노년층에서 더 주제에 서 벗어난 낱말을 많이 산출하였거나(James et al., 1998), 주제 에서 벗어난 발화의 비율이 높거나(Ruffman et al., 2010), 1 7 점 척도로 주제 유지를 측정하였을 때, 그 점수가 떨어졌음 (Trunk \& Abrams, 2009)이 보고되었다.

그러나 주제에 맞는 발화인지 아닌지로 시간이나 양을 측정 하는 방법, 즉 정오반응식의 측정법은 그 판단에 한계가 있을 수 있으며, 따라서 보다 세분화하여 발화가 주제에 어느 정도 로 근접한지를 측정하는 것이 더 타당할 수 있다. 또한, 등간 척 도로 인터뷰 문항에 대한 각각의 담화마다 점수를 준 방법은 담화 과제의 주제를 생활사(life history) 인터뷰나 전기적(autobiographical) 내러티브 과제에 국한하였다. 또한, 위 연구들 의 노년층 평균 연령이 70대에 국한되어 있으며, 70대와 20 30 대의 발화를 비교한 연구이므로 노년층 내에서의 주제에서 벗 어난 발화 정도를 조사하기에 바람직하지 않다.

이에 본 연구는 주제에서 벗어난 정도를 여러 담화 과제에 적
용하여 측정하기 위해 통일성(coherence)의 개념을 적용하고자 한다. 통일성이란 논의되는 주제를 개시하고 계획하고 유지하 는 화자의 능력을 표상하는 표현 언어 수행의 측정법이다(Ellis et al., 2016). 또는 분석하고자 하는 발화의 의미 및 내용과 담화 의 전체 주제 간의 관계를 일컫는다. 통일성 분석은 각 발화단위 에 1 4점 또는 1 5점을 주어 그 값을 평균하여 산정하는 방법 (Wright et al., 2013, 2014), 통일성에 위배되는 발화의 비율을 측 정하는 방법(Andreetta et al., 2012; Marini et al., 2014), 담화의 통일성 유지 정도를 판단하여 전체 담화에 1 4점을 주는 방법 (Race et al., 2015)이 있다. 오류에 초점을 둔 분석은 화자의 목 표, 담화의 주제나 개념에 기여하는 정보에 대한 분석이 빠지기 쉽다는 보고에 따라(Ellis et al., 2016), 본 연구는 각 발화단위에 점수를 주어 그 값을 평균 내는 방법을 사용하고자 한다.

담화의 효율성, 혹은 정보성은 CU (Yorkston \& Beukelman, 1980)와 CIU (Nicholas \& Brookshire, 1993)로 분석되어 왔다. 그러나 본 분석 기법들에 다소 한계가 있는데, $\mathrm{CU}$ 는 미리 정한 중요 정보를 실은 단어나 어구를 세어 전체 담화에서의 비율을 측정하거나, 분당 얼마의 $\mathrm{CU}$ 를 산출했는가를 측정하는 것으 로, $\mathrm{CU}$ 에 해당하는 내용이 무엇인지를 미리 정해야 된다는 점 에서 그림 설명하기 과제나 절차 설명하기 과제와 같은 뚜렷한 목표발화가 있는 담화 과제에 한정된다. CIU의 경우, 산출된 전 체 단어 수에서 문맥상 적절하고 의미 있는 단어의 수가 차지 하는 비율을 측정하는 법으로 최근까지 이용되어 왔으나(Choi \& Lee, 2017), Nicholas \& Brookshire(1993)의 CIU 분석 매뉴 얼을 온전히 익혀서 사용하기에는 많은 시간과 노력이 필요하 며, 그 적용 가능성을 실험해보고자 한 연구에서는 본 CIU 분석 법을 익히지 않은 연구자가 채점한 CIU 비율의 신뢰도는 $55 \%$ 로, 비교적 높지 않은 신뢰도를 보였다(Pedhazur \& Schmelkin, 2013). 이에 비해 본 연구에서 정보성 측정을 위해 사용하고자 하는 분석 단위인 명제(proposition)는 하나의 술어와 그 술어에 속하는 하나 또는 그 이상의 논항 구조로 구성된 의미 있는 가 장 작은 문장으로서(Bryant et al., 2013), 술어를 중심으로 명제 를 구별하므로 그 분석이 용이하다.

이에 본 연구는 노화에 따른 담화 수행 정도의 변화를 알아 보고자, 주제 유지 정도를 통일성 분석으로 효율성 정도를 명제 밀도 분석으로 살펴보고자 하였다. 특히, 본 연구에서는 75 84 세의 중고령층(middle-old)과 85세 이상의 초고령층(old-old) (Burda, 2010)의 담화 수행 능력의 차이를 조사한다. 통계청의 추계인구에서 65세 이상의 고령인구는 2015년 654만여 명(전체 인구의 12.8\%)에서 2018년에 738만여 명(14.3\%)으로 증가했으 며, 이 중 70세 이상의 인구는 443만 명(8.7\%)에서 502만 명 (9.7\%)으로, 80세 이상의 인구는 135만 명(2.6\%)에서 164만 명 (3.2\%)으로 증가하였다(Statistics Korea, 2018). 기존 정상 노년 
층의 담화 산출에 대한 연구에서는 65 세를 기점으로, 혹은 75 세를 기점으로 담화 수행 정도를 조사하였으나, 85세를 기점으 로 담화 수행 정도를 조사한 연구는 전무하다. 따라서 85세 이 상의 담화 수행에 대한 규준이 없으며, 이는 초고령층의 발화 가 정상 노화에 의한 담화 수행의 저하인지, 혹은 병리적인 이 유(예컨대 경도인지장애나 뇌졸중 등)에 의한 저하인지를 알 수 없다. 따라서, 본 연구의 목적은 다음과 같다. 85 세를 기점으 로 중고령층과 초고령층의 담화 수행력의 차이를 통일성과 명 제밀도 분석을 통해, 주제 유지 정도와 효율성의 측면에서 비 교한다. 또한, 담화 산출의 통일성 및 효율성에 대한 측정치들 과 인구통계학적 정보, 언어검사 및 한국판 간이정신상태검사 (the Korean version of the Mini-Mental State Examination, $\mathrm{K}-\mathrm{MMSE})$ 와의 상관관계를 조사한다.

\section{MATERIALS AND METHODS}

\section{연구 대상}

본 연구는 노화 및 신경학적 질환에 기인한 인지-언어적 양 상 연구의 일부분으로, 2018년 7월부터 8월까지 두 달간 서울 지역에 거주하고 있는 총 20 명의 고령층 대상자가 수집되었다. 이 중 $\mathrm{K}-\mathrm{MMSE}$ 를 실시하지 못한 2 명의 대상자가 제외되었으 며, 본 연구의 중고령층의 연령 기준보다 적은 1명(74세)이 제외 되어, 총 17 명이 본 연구 대상자로 선정되었다. 17 명 중 11 명은 중고령층, 6 명은 초고령층이었다. 또한, 본 연구의 대상자는 1) $\mathrm{K}-$ MMSE 규준에서 점수가 정상 범주에 속하며(Han et al., 2008), 2) 뇌졸중, 치매, 경도인지장애 등의 인지적 능력에 영향을 미칠 신경학적 질환을 진단받은 적이 없으며, 3) 짧은 문장을 읽고 낱 말 수준의 받아쓰기가 가능한, 즉 문해력이 있는 대상자가 포함 되었다. 연구 대상자의 정보는 Table 1에 제시하였다. Table 1에 제시된 남녀 성비, 교육 연수, $\mathrm{K}-\mathrm{MMSE}$, 간이우울증검사(the short version of Geriatric Depression Scale, GDS)에서 두 집단 간 차이는 유의하지 않았다.

\section{담화 과제}

담화 과제 총 3 가지는 구어지시로 제시되는 2 가지 과제, 그 림과 구어지시가 제시되는 1가지 과제로 이루어졌다. 자녀를 키 우면서 좋았던 일이나 힘들었던 일을 회상하여 말하기, 뉴욕 여행 계획 세우기 과제를 번안한(Fleming, 2014) 제주도 여행 계획 세우기가 구어지시로 이루어진 과제이며, 그림 설명하기 는 Kim et al.(2009)의 일부 수정된 그림을 이용하였다.

\section{연구 절차}

연구 대상자들에게 본 연구의 목적과 절차를 설명하고 동의
Table 1. Demographic characteristics of middle-old and old-old elderly

\begin{tabular}{lccc}
\hline & Middle-old $(\mathrm{n}=11)$ & Old-old $(\mathrm{n}=6)$ & $p$ \\
\hline Age, $\mathrm{y}$ & $79.00 \pm 2.76$ & $89.67 \pm 3.78$ & $0.001^{*}$ \\
M:F & $2: 9$ & $0: 6$ & 0.266 \\
Education, $\mathrm{y}$ & $7.63 \pm 4.46$ & $7.17 \pm 4.30$ & 0.646 \\
K-MMSE & $25.27 \pm 4.94$ & $23.50 \pm 4.72$ & 0.312 \\
GDS & $7.18 \pm 4.05$ & $4.75 \pm 2.22$ & 0.357 \\
\hline
\end{tabular}

${ }^{*} p<0.01$. Y: year, M: male, F: female, K-MMSE: the Korean version of the Mini-Mental State Examination, GDS: the short version of Geriatric Depression Scale

서에 서명하도록 하였다. 그 후, 짧은 구를 읽고 읽은 내용을 묻 는 질문 두 개에 답하기, 단어 받아쓰기를 통한 문해력 검사를 실시하였다. 과거 진단받은 신경학적 질환 여부와 교육 수준 등 을 묻는 인구통계학적 설문을 마친 뒤, GDS, K-MMSE 검사 를 실시하였다. 이후, 언어검사의 일환으로 1 분 동안의 동물이 름대기검사와 15 개 문항의 한국판 보스턴 이름대기검사 단축 형(the 15-item Korean version of the Boston Naming Test, KBNT-15) (Kim \& Kim, 2013)이 진행되었다. 본 언어검사 후, 위에 제시된 3개 담화 과제가 실시되었다. 대상자의 모든 담화 과제는 오디오 녹음되었으며, 철자법 표기를 준수하여 화자가 말한 그대로 마이크로소프트 2010 워드 문서(Microsoft, Redmond, WA, USA)에서 전사되었다.

\section{담화 분석 및 신뢰도}

전사된 담화는 전사자료와 녹음자료를 이용하여, 발화단위 로 나뉘었다(Kim, 2016). 전사자료의 통일성과 명제밀도 분석은 다음과 같다. 첫째, 통일성은 각 발화단위에 1 4점의 점수가 주 어지고, 그 점수의 평균값으로 산정되었다(Wright \& Capilouto, 2012; Wright et al., 2013, 2014). 통일성에 관한 채점 기준 및 예 시는 Appendix 1에 제시되었다. 또한, 본 점수에 대한 검사자 간 신뢰도를 위해 총 51 개의 담화 중 약 $20 \%$ 에 해당하는 9 개 의 담화(중고령층 2 명과 초고령층 1 명의 담화)를 추출하였다. 이 9 개 담화는 본 연구의 세 가지 담화 과제와 통일성 채점 기 준(Appendix 1)에 대한 설명을 들은 언어재활사 1급 자격증 소 지자가 채점하게 하였다. 그 결과 신뢰도는 $85.1 \%$ 로 산정되었 다. 둘째, 명제밀도는 각 발화를 명제단위로 나누었으며(Kim, 2016), 반복되는 명제, 내용과 전혀 상관이 없는 명제를 제외한 명제의 수를 세어 전체 산출된 명제 수로 나누어 그 비율을 산 출하였다.

\section{통계 분석}

중고령층과 초고령층의 집단 간 언어검사 과제 수행 정도와 담화 수행 정도를 비교하기 위해, 비모수 검정법인 맨 휘트니 
유 검정(Mann-Whitney U test)을 실시하였다. 또한, 75세 이 상의 고령층 담화 과제 수행과 인구통계학적 정보와의 상관성 분석을 위해, 스피어만 상관관계 분석을 실시하였다. 또한, 담 화 과제 수행과 $\mathrm{K}-\mathrm{MMSE}$ 및 언어검사 결과와의 상관성을 위 해 연령을 통제한 편상관 분석을 실시하였다.

\section{RESULTS}

\section{중고령층과 초고령층의 담화 수행 비교}

중고령층과 초고령층의 언어검사 결과, 담화 수행의 기술적 집단 통계량은 Table 2에 제시되었다. 두 집단이 산출한 총 발 화 수와 담화 산출에 소요된 시간(초), 총 단어 수, 그리고 총 명제 수에서 통계적으로 유의한 차이는 없었으나, 초고령층이 전반적으로 더 많은 양의 발화를 산출하였다. 또한, 언어검사 결 과에서도 두 집단 간 통계적 차이는 나타나지 않았다. 또한, 두 집단 간 통일성과 명제밀도의 차이가 있는지 맨 휘트니 유 검정 으로 확인한 결과, 통일성에서는 차이가 없었으며 $(\mathrm{U}=14.000$, $p=0.062)$, 명제밀도에서 두 집단 간 차이가 있었다 $(\mathrm{U}=7.000$, $p=0.007$ ) (Table 3).

\section{고령층 담화 수행과 인구통계학적 정보 및 언어검사와의 상관성}

통일성 점수와 명제밀도를 인구통계학적 정보와 상관 비교 한 결과, 통일성 점수는 연령이 증가할수록 낮아지는 경향이 있 었으며 $(\mathrm{r}=-0.566, p=0.018)$ 명제밀도 또한, 연령이 증가할수 록 낮아졌다 $(\mathrm{r}=-0.496, p=0.043)$ (Table 4). 또한, 통일성 점수

Table 2. Quantitative description of discourse production and language tests of middle-old and old-old elderly

\begin{tabular}{lcc}
\hline & Middle-old & Old-old \\
\hline Discourse production & & \\
Total number of utterances & $8.55 \pm 4.02$ & $10.94 \pm 6.13$ \\
Total talking time (sec) & $44.67 \pm 21.75$ & $57.22 \pm 28.96$ \\
Total number of words & $57.39 \pm 34.79$ & $75.67 \pm 43.59$ \\
Total number of propositions & $17.00 \pm 7.55$ & $22.28 \pm 11.70$ \\
Language test & & \\
Verbal fluency (animal) & $12.36 \pm 2.58$ & $11.17 \pm 3.06$ \\
K-BNT-15 & $10.27 \pm 3.29$ & $8.00 \pm 4.24$ \\
\hline
\end{tabular}

Sec: seconds, K-BNT-15: the 15-item Korean version of the Boston Naming Test

Table 3. Comparison of coherence and propositional density in middle-old and old-old elderly

\begin{tabular}{lrcrc}
\hline & Middle-old & Old-old & \multicolumn{1}{c}{$\mathrm{U}$} & $p$ \\
\hline Coherence & $2.89(0.49)$ & $2.20(0.75)$ & 14.000 & 0.062 \\
Propositional density & $77.17(8.19)$ & $56.82(16.14)$ & 7.000 & $0.007^{*}$ \\
$(\%)$ & & & & \\
\hline
\end{tabular}

Score: median (quartile). ${ }^{*} p<0.01$. U: U value of Mann-Whitney
및 명제밀도와 K-MMSE, 언어검사 점수와의 상관관계를 보기 위해, 6년 이상의 교육 연수(Cheon, 2011; Lee \& Kim, 2001)와 우울감(Mueller et al., 2018; Murray, 2010)이 노년층 담화 산출 과 관련이 없었다는 선행연구에 따라, 연령을 통제한 편상관 분 석을 실시하였다. 그 결과, $\mathrm{K}-\mathrm{MMSE}$ 와 $\mathrm{K}-\mathrm{BNT}-15$ 점수가 높을 수록, 통일성 점수는 높았다 $(\mathrm{r}=0.506, p=0.046 ; \mathrm{r}=0.554, p=$ 0.026) (Table 5).

\section{DISCUSSIONS}

본 연구를 통해 75 세 이상의 노년층에서 85 세를 기점으로 주 제 유지 정도와 담화 산출의 효율성이 유지되는지를 살펴보았 다. 주제 유지 정도, 즉 통일성은 나이가 증가함에 따라 낮아지 는 경향성을 보였으나, 85 세를 기점으로 비교해 보았을 때는, 중 고령층과 초고령층 사이에서 차이가 나타나지 않았다. 반면, 효 율성은 나이가 능가함에 따라 낮아졌으며, 85세를 기점으로 $10 \%$ 이상의 차이를 보였다.

본 연구와 같은 1 4점 발화에 점수를 주는 통일성 분석 방 식을 쓴 정상인을 대상으로 한 선행연구에서 평균 28.98세의 40 명과 76.98세의 40명을 대상으로 1개의 그림 보고 이야기하기, 6 개 그림 보고 이야기하기, 텍스트가 없는 그림책 보고 이야기하 기, 경험 이야기하기, 절차 설명하기의 5 개 과제를 비교한 바 있 다(Wright et al., 2014). 선행연구에서는 위 다섯 가지 담화 과제 중 유일하게 경험 이야기하기 과제에서 젊은 층과 노년층의 통일 성 점수에서 유의한 차이를 보였다. 본 연구에서의 통일성 점수 차이를 각 과제별로 살펴보면, 제주도 여행 계획 세우기 과제에 서 가장 큰 차이를 보였으며, 자녀 양육에 대한 경험 말하기 과 제에서 가장 적은 차이를 보였다. 이로 미루어 보아, 제주도 여 행 계획 세우기 과제는 절차 설명하기와 내러티브의 요소를 동 시에 포함하고 있으며, 계획하기, 조직능력, 인지적 유연성을 요

Table 4. Correlations between discourse measures and demographic information

\begin{tabular}{lccc}
\hline & Age & Education & GDS \\
\hline Coherence & $-0.566^{*}$ & 0.389 & -0.185 \\
Propositional density & $-0.496^{*}$ & 0.446 & -0.205 \\
\hline
\end{tabular}

${ }^{*} p<0.05$. GDS: the short version of Geriatric Depression Scale

Table 5. Correlations among discourse measures, K-MMSE, and language tests

\begin{tabular}{lccc}
\hline & K-MMSE & Verbal fluency & K-BNT-15 \\
\hline Coherence & $0.506^{*}$ & 0.272 & $0.554^{*}$ \\
Propositional density & 0.360 & -0.259 & 0.303 \\
\hline
\end{tabular}

Controlling for age. ${ }^{*} p<0.05$. K-MMSE: the Korean version of theMini-Mental State Examination, verbal fluency: verbal fluency of animal category, K-BNT-15: the 15-item Korean version of the Boston Naming Test 
구하는 과제이기에(Fleming \& Harris, 2008), 중고령층과 초고 령층에서 이러한 인지적 요구가 높은 과제에 있어 가장 큰 점 수 차이를 보였다. 또한, 위 선행연구에서 노년층의 통일성 점수 는 평균 3.75점으로, 본 연구의 통일성 평균 점수가 중고령층이 2.83점, 초고령층이 2.38점인 것보다 다소 높은 점수였다. 이는 첫째, 선행연구의 평균 연령이 75세 전후였던 데 비해, 본 연구 의 중고령층과 초고령층의 평균 연령은 각각 79세와 89세로 연 령의 증가에 따른 노화에 의해 담화 산출 주제 유지의 어려움 이 반영되었을 수 있다. 둘째, 본 연구 과제 중 두 개의 구두로 만 제시되는 경험에 대해 이야기하기와 여행을 가기 위한 계획 세우기 과제는 그림 속의 특정 이야기를 산출하거나 정해진 절 차(샌드위치 만들기와 정원에 꽃 심기)를 설명하도록 유도한 선 행 연구의 과제에 비해 난이도가 높았을 것으로 예상된다. 동시 에 선행연구에서도 유일하게 젊은 층과 노년층에서의 통일성 점수에 차이가 났었던 과제는 경험 이야기하기 과제로, 이는 그 림이 제시되어 특정 목표가 있는 과제보다 경험 이야기하기 과 제가 발화자로 하여금 내러티브 구조를 더 예측할 수 없게 하 기 때문이다(Wright et al., 2014).

또한, 본 연구에서 노년층의 통일성 점수는 대면이름대기검사 와 유의한 상관성이 있는 것으로 나타났다. 대면이름대기검사 는 그림 자극을 지각, 자극 그림을 의미론적으로 식별, 사전적 인 인출, 그리고 목표 단어에 음운론적으로 접근하는 일련의 과정을 순차적으로 요구하는 과제로서(Burke \& Shafto, 2004), 노년층의 단어인출(word retrieval)의 어려움을 측정할 수 있는 민감한 과제이다(Connor et al., 2004). 담화 분석상 그룹 간 통 일성 점수에서 가장 큰 차를 보였던 여행 계획 세우기 담화 과 제를 예로 들면, 높은 통일성 점수를 위해서는 준비물, 교통, 숙 박, 여행지에서의 할 일에 대한 적절한 단어인출이 필수적이다. 또한, 그림 설명 과제도 그림 속의 주요 단어들을 인출하는 능 력이 통일성 유지를 위해 필수적이다. 명칭 실어증 환자의 통일 성 분석에서 보고된 바에 의하면, 단어인출의 어려움은 환자의 발화를 근본적으로 방해하여, 문장 완성도의 수준을 감소시켜 서 전체 발화의 통일성 정도를 감소시킨다. 또한, 사전적 손상 (lexical impairment)을 대처할 전략을 사용하여, 삽입어 사용 이나 앞의 발화의 반복으로 통일성을 저해하는 발화들이 무리 를 이루게 되어(clustered), 통일성 수준이 낮아지게 된다(Andreetta et al., 2012).

노년층 담화의 통일성 측정과 인지기능과의 관계를 본 선행 연구들은 특히, 통일성 점수가 집행기능(Lê et al., 2014; Marini et al., 2014) 및 기억력(Lê et al., 2014)과 관련된다고 보고하였 다. 본 연구에서는 통일성이 전반적 인지능력, 즉 K-MMSE와 상관성이 있었다. 통일성 있는 담화를 산출하기 위해서는 과제 의 주제를 담화 시작 시점부터 끝날 때까지 염두에 두면서, 동
시에 문장을 산출하는 능력이 요구된다. 이러한 능력이 전반적 인 인지기능과 연관될 수 있음을 본 연구결과가 시사한다.

명제밀도 분석은 영어권에서는 이미 자동화되어 그 신뢰도 가 인정되었으며(Brown et al., 2008), 발화의 의미적 풍부함을 분석할 수 있고(Smolík et al., 2016), 특히, 한국어 화자의 발화 분석에서는 한국어의 언어 특성상 술어의 사용이 두드러지기 때문에(Sung et al., 2016), 한국어 화자의 담화 산출의 효율성을 보기에 유용하다. 본 연구의 명제밀도는 반복되거나 과제와 전 혀 상관이 없는 명제를 제외한 새로운 명제(novel proposition) 가 전체 산출된 명제에서 차지하는 비율을 산정한 값이다(Law et al., 2015). 따라서 명제밀도는 담화의 정보성, 즉, 정보 전달의 효율성을 보기에 적합하다(Bryant et al., 2013; Law et al., 2015).

담화의 정보성을 본 정상 노년층의 선행연구에서 40 59세 집 단, 60 74세 집단, 75 88세 집단 간 Cookie Theft 그림의 CU 를 분석한 결과, 40 59세 집단과 75 88세 집단 간의 차이가 유 의하였으나, 60 74세 집단과 75 88세 집단 간 차이는 나타나지 않았다(Mackenzie, 2000). 이와 유사하게, 젊은 노년층(60 74 세)과 나이 든 노년층(75 84세)을 Picnic 그림 설명하기 과제와 6개 일련의 그림 보고 이야기하기 과제에서 적절한 내용의 단 어 수와 적절한 내용의 주제 수의 비율을 산정한 연구에서는 두 연령층 사이에 차이가 나타나지 않았으나, 다만 20 39세 사 이의 젊은 층과 비교했을 때 나이 든 노년층이 수행력의 차이 를 보였다(Marini et al., 2005). 또한, 국내연구에서는 정상 노 년층을 대상으로 Picnic 그림 설명하기 과제로 $\mathrm{CIU}$ 를 비교하 였으나, 65 세를 기점으로 청년층 및 중년층과 비교했을 때도 $\mathrm{CIU}$ 비율에서는 그룹 간 차이가 나타나지 않았다(Kwon et al., 1998; Lee \& Kim, 2001). 이상에서 보는 바와 같이, 65세를 기 점으로는 효율성의 감퇴가 나타나지 않으며, 75 세를 기점으로 한 노년층에서는 젊은 층에 비해서는 그 효율성이 떨어지지만, 60 74세의 젊은 노년층 집단과는 발화의 효율성 측면에서 차이 가 나타나지 않았음을 시사한다. 이에 본 연구에서는 85 세를 기 점으로 하여, 중고령층에 비해 85세 이상 초고령층의 담화 산출 에서 효율성이 떨어짐을 밝혀냈다. 본 연구에서 주지할 점은 85 세 이상의 초고령층이 전체 단어 수 및 총 발화 시간에서 중고령 층에 비해 상대적으로 많은 발화를 산출하였으며, 따라서 새로 운 명제를 산출하는 비율은 유의하게 감소하였다는 점이다.

정상 노년층에서 노화에 따른 담화 산출의 변화는 문장의 복 잡성, 통사적, 사전적 산출 오류와 같은 미시언어적(microlinguistic) 능력이 보존되는 반면, 통일성, 응집성 및 정보성과 같 은 거시언어적(macrolinguistic) 능력이 감퇴한다(Glosser \& Deser, 1992). 최근에 이르러서도 거시언어능력의 변화 정도를 측정한 연구에서, 경도 알츠하이머병과 기억상실형 경도인지장 애 환자, 정상군을 대상으로 자동화된 프로그램을 통해 담화 
의 주요 자질을 추출하여, 이러한 병리적 담화 산출에서 핵심 명제가 점차 감소됨이 보고되었다(Toledo et al., 2017). 또한, 123 명의 정상군(55 84세)을 대상으로 내러티브의 통일성, 응집 성, 정보성의 수행력을 토대로 군집 분석(cluster analysis)한 연 구에 따르면, 담화의 정보성이 가장 낮은 군집이 타 언어검사 과제에서의 수행이 가장 낮았으며, 이는 언어능력 감퇴를 담화 과제가 민감하게 탐지할 수 있음을 시사한다(Pistono et al., 2017). 본 연구는 초고령층의 거시언어적 능력의 감퇴를 두 가 지 측정을 통해 구체적으로 기술하였다. 이를 통해 병리적인 이 유로 담화 산출이 저하된 초고령층 환자군의 수행이 노화에 의한 것인지, 병리적 이유 때문인지를 비교하는 데 본 연구결과 를 참조할 수 있을 것이다. 또한, 85세 이상의 담화 산출능력을 측정할 때, 본 연구자료를 규준으로 활용할 수 있을 것이다. 다 만, 통일성이나 정보성과 같은 언어능력에 대한 정보를 얻기 위 해, 전사와 복잡한 과정의 분석을 거쳐야 함이 아직까지도 담 화를 임상에 적용할 수 없게 하는 한계이며, 따라서 영어권 또 는 그 외의 언어에서 담화의 자동화된 분석이 시도되어 왔다 (Bryant et al., 2013; Garrard et al., 2014; Toledo et al., 2017). 본 연구는 다음의 한계점을 갖는다. 첫째, 본 연구에서 75 세 미만의 젊은 노년층이 포함되지 않았기 때문에, 젊은 노년층과 중고령층, 초고령층의 직접적 비교는 불가능하였다. 본 연구와 같은 방법을 적용하여 직접 비교를 한다면, 노화에 따른 담화 능력의 감퇴가 어느 시점에서 급속히 저하되는지 확인할 수 있 을 것이다. 둘째, 신경심리검사를 수행할 수 없었기 때문에 담 화 측정을 세부적인 인지능력과 비교할 수 없었다. 정상 노년층 의 인지 영역과 담화 측정과의 관계를 확인함으로써, 특정 인지 능력의 감퇴가 담화에 미치는 영향을 파악하는 데 도움이 될 수 있을 것이다.

중심 단어 : 담화·노화·통일성·명제 분석·언어능력.

\section{Ethical Statement}

This study was approved by the Institutional Review Board of the Hallym University of Graduate Studies (IRB\#: HUGSAUD461850).

\section{Acknowledgments}

The authors thank to the participants.

\section{Declaration of Conflicting Interests}

There are no conflict interests.

\section{Funding}

N/A

\section{REFERENCES}

Andreetta, S., Cantagallo, A., \& Marini, A. (2012). Narrative discourse in anomic aphasia. Neuropsychologia, 50(8), 1787-1793.

Arbuckle, T. Y. \& Gold, D. P. (1993). Aging, inhibition, and verbosity. The
Journals of Gerontology, 48(5), 225-232.

Arbuckle, T. Y., Pushkar, D., Bourgeois, S., \& Bonneville, L. (2004). Offtarget verbosity, everyday competence, and subjective well-being. Gerontology, 50(5), 291-297.

Brown, C., Snodgrass, T., Kemper, S. J., Herman, R., \& Covington, M. A. (2008). Automatic measurement of propositional idea density from part-of-speech tagging. Behavior Research Methods, 40(2), 540-545.

Bryant, L., Spencer, E., Ferguson, A., Craig, H., Colyvas, K., \& Worrall, L. (2013). Propositional idea density in aphasic discourse. Aphasiology, 27(8), 992-1009.

Burke, D. M. \& Shafto, M. A. (2004). Aging and language production. Current Directions in Psychological Science, 13(1), 21-24.

Choi, H. \& Lee, J. Y. (2017). Relationship to ratio of correct information unit and cognitive functions in patients with amnestic MCI and EAD. Communication Sciences and Disorders, 22(3), 550-560.

Connor, L. T., Spiro, A. 3rd., Obler, L. K., \& Albert, M. L. (2004). Change in object naming ability during adulthood. The Journals of Gerontology, Series B: Psychological Sciences and Social Sciences, 59(5), 203-209.

Ellis, C., Henderson, A., Wright, H. H., \& Rogalski, Y. (2016). Global coherence during discourse production in adults: A review of the literature. International Journal of Language and Communication Disorders, 51(4), 359-367.

Fleming, V. B. (2014). Early detection of cognitive-linguistic change associated with mild cognitive impairment. Communication Disorders Quarterly, 35(3), 146-157.

Fleming, V. B. \& Harris, J. (2008). Complex discourse production in mild cognitive impairment: Detecting subtle changes. Aphasiology, 22(7-8), 729-740.

Garrard, P., Rentoumi, V., Gesierich, B., Miller, B., \& Gorno-Tempini, M. L. (2014). Machine learning approaches to diagnosis and laterality effects in semantic dementia discourse. Cortex, 55, 122-129.

Glosser, G. \& Deser, T. (1992). A comparison of changes in macrolinguistic and microlinguistic aspects of discourse production in normal aging. Journal of Gerontology, 47(4), P266-P272.

Han, C., Jo, S. A., Jo, I., Kim, E., Park, M. H., \& Kang, Y. (2008). An adaptation of the Korean mini-mental state examination (K-MMSE) in elderly Koreans: Demographic influence and population-based norms (the AGE study). Archives of Gerontology and Geriatrics, 47(3), 302-310.

James, L. E., Burke, D. M., Austin, A., \& Hulme, E. (1998). Production and perception of "verbosity" in younger and older adults. Psychology and Aging, 13(3), 355-367.

Kim, B. S. (2016). Discourse measures to differentiate between mild cognitive impairment and the normal elderly (Unpublished doctoral thesis). Yonsei University, Seoul.

Kim, H., Heo, J. H., Kim, D. Y., \& Kim, J. (2009). Screening Test for Aphasia and Neurologic-Communication Disorders. Seoul: Hakjisa.

Kim, H. \& Kim, S. R. (2013). Development of short form of the Korean version- the Boston Naming Test (K-BNT-15) based on item response theory. The Journal of the Korea Contents Association, 13(12), 321-327.

Kwon, M., Kim, H., Choi, S., Na, D. L., \& Lee, K. H. (1998). A study for analyzing spontaneous speech of Korean adults with CIU scoring system. Communication Sciences and Disorders, 3(1), 35-49.

Law, B., Young, B., Pinsker, D., \& Robinson, G. A. (2015). Propositional speech in unselected stroke: The effect of genre and external support. Neuropsychological Rehabilitation, 25(3), 374-401.

Lê, K., Coelho, C., Mozeiko, J., Krueger, F., \& Grafman, J. (2014). Does brain volume loss predict cognitive and narrative discourse performance following traumatic brain injury? American Journal of Speech-Language Pathology, 23(2), S271-S284.

Lee, Y. M. \& Kim, H. (2001). An utterance analysis of conversations and picture description tasks of Korean adults. Communication Sciences and Disorders, 6(1), 1-11.

Mackenzie, C. (2000). Adult spoken discourse: The influences of age and education. International Journal of Language and Communication Disorders, 35(2), 269-285. 
Marini, A., Boewe, A., Caltagirone, C., \& Carlomagno, S. (2005). Age-related differences in the production of textual descriptions. Journal of Psycholinguistic Research, 34(5), 439-463.

Marini, A., Zettin, M., \& Galetto, V. (2014). Cognitive correlates of narrative impairment in moderate traumatic brain injury. Neuropsychologia, 64, 282-288.

Mortensen, L., Meyer, A. S., \& Humphreys, G. W. (2006). Age-related effects on speech production: A review. Language and Cognitive Processes, 21(1-3), 238-290.

Nicholas, L. E. \& Brookshire, R. H. (1993). A system for quantifying the informativeness and efficiency of the connected speech of adults with aphasia. Journal of Speech, Language, and Hearing Research, 36(2), 338350.

Pedhazur, E. J. \& Schmelkin, L. P. (2013). Measurement, Design, and Analysis: An Integrated Approach. New York, NY: Psychology Press.

Pistono, A., Pariente, J., Bézy, C., Pastor, J., Tran, T. M., Renard, A., et al. (2017). Inter-individual variability in discourse informativeness in elderly populations. Clinical Linguistics and Phonetics, 31(5), 391-408.

Race, E., Keane, M. M., \& Verfaellie, M. (2015). Sharing mental simulations and stories: Hippocampal contributions to discourse integration. Cortex, 63, 271-281.

Ruffman, T., Murray, J., Halberstadt, J., \& Taumoepeau, M. (2010). Verbosity and emotion recognition in older adults. Psychology and Aging, 25(2), 492-497.

Smolík, F., Stepankova, H., Vyhnálek, M., Nikolai, T., Horáková, K., \& Matejka, $\breve{S}$. (2016). Propositional density in spoken and written language of Czech-speaking patients with mild cognitive impairment. Journal of Speech, Language, and Hearing Research, 59(6), 1461-1470.

Statistics Korea (2018, September 1). Projected Population by Age Group (Korea). Korean Statistical Information Service (KOSIS). Retrived from
http://kosis.kr/statHtml/statHtml.do?orgId=101\&tblId=DT_1BPA003 $\& v w \_c d=\& l i s t \_i d=\& s c r I d=\& s e q N o=\& l a n g \_$mode $=k o \& o b j \_v a r$ id=\&itm_id=\&conn_path=B1\&path=\%252Fconts\%252FnsportalStats \%252FnsportalStats_0102Body.jsp.

Sung, J. E., DeDe, G., \& Lee, S. E. (2016). Cross-linguistic differences in a picture-description task between Korean- and English-speaking individuals with aphasia. American Journal of Speech-Language Pathology, 25(4S), S813-S822.

Toledo, C. M., Aluísio, S. M., Dos Santos, L. B., Brucki, S. M. D., Trés, E. S., de Oliveira, M. O., et al. (2017). Analysis of macrolinguistic aspects of narratives from individuals with Alzheimer's disease, mild cognitive impairment, and no cognitive impairment. Alzheimer's and Dementia: Diagnosis, Assessment and Disease Monitoring, 10, 31-40.

Trunk, D. L. \& Abrams, L. (2009). Do younger and older adults' communicative goals influence off-topic speech in autobiographical narratives? Psychology and Aging, 24(2), 324-337.

Wright, H. H. \& Capilouto, G. J. (2012). Considering a multi-level approach to understanding maintenance of global coherence in adults with aphasia. Aphasiology, 26(5), 656-672.

Wright, H. H., Capilouto, G. J., \& Koutsoftas, A. (2013). Evaluating measures of global coherence ability in stories in adults. International Journal of Language and Communication Disorders, 48(3), 249-256.

Wright, H. H., Koutsoftas, A. D., Capilouto, G. J., \& Fergadiotis, G. (2014). Global coherence in younger and older adults: Influence of cognitive processes and discourse type. Aging, Neuropsychology and Cognition, 21(2), 174-196.

Yorkston, K. M. \& Beukelman, D. R. (1980). An analysis of connected speech samples of aphasic and normal speakers. Journal of Speech and Hearing Disorders, 45(1), 27-36. 


\section{APPENDIX $\square$}

\section{Coherence Scoring Instructions}

\section{제주도 여행 계획하기}

\begin{tabular}{|c|l|}
\hline 4 & $\begin{array}{l}\text { '교통편', ‘준비물', ‘숙박’, ‘제주도에서의 활동’에 관한 실질적 정보가 포함 } \\
\text { 예: 교통편(비행기, 렌터카), 준비물[음식: 간식, 김치, 반찬, 물; 의류: 속옷, 잠옷, 비옷, 수영복; 복용하고 있는 약; 기타: 돈, } \\
\text { 신분증, 복지카드, (신용)카드], 숙박(호텔, 펜션, 여관), 활동(올레길, 미술관, 박물관, 해변가, 노래방, 외식) 등 }\end{array}$ \\
\hline 3 & $\begin{array}{l}\text { 주제 ‘제주도 여행'과 연관되지만 실질적 정보가 들어있지 않은 경우 } \\
\text { 예: 이렇게 해서 (잘) 가져가다, 즐겁게 지내다 오다, 구경하다 }\end{array}$ \\
\hline 2 & $\begin{array}{l}\text { 주제 ‘제주도 여행'과 직접적으로 연관되지는 않으나, 무관하지는 않은 내용 } \\
\text { 예: 본인 이야기(여행 선호, 제주도 여행 경험담, 해외여행 경험담), 제주도에 대한 설명, 앞 내용의 반복 }\end{array}$ \\
\hline 1 & $\begin{array}{l}\text { 주제와 전혀 관련 없는 내용 } \\
\text { 예: 본인 처지(재정 상태, 건강 상태), 질문 다시 묻기 및 질문의 반복 }\end{array}$ \\
\hline
\end{tabular}

\section{자녀 키울 때의 경험 묻기}

\begin{tabular}{|c|l|}
\hline 4 & $\begin{array}{l}\text { 과거 ‘자녀 양육에서의 좋았던 일이나 힘들었던 일’에 대한 실질적 정보 포함 } \\
\text { 예: 자녀 학창 시절 성적(“공부를 정말 잘했었어”, “중학교 들어가서 1등 했어”), 자라 오면서 품성 “말썽 안 부리고 참 착했 } \\
\text { 어요”, 에피소드에 속하는 발화(자녀가 아팠던 에피소드, 어린이날 에피소드 등) }\end{array}$ \\
\hline 3 & $\begin{array}{l}\text { ‘자녀'에 연관되지만 키울 때의 경험에 대한 실질적 정보가 없는 경우 } \\
\text { 예: 일반적 사실에 대한 발화(“힘들 때도 있고 좋을 때도 있지요”, “사는 게 그렇지요”, “그냥 길렀어” 등), 자녀 현재 이야기 } \\
\text { (자녀 자랑, “지금 삼에서 과장으로 있어”) }\end{array}$ \\
\hline 2 & $\begin{array}{l}\text { ‘자녀 양육에서의 좋았던 일이나 힘들었던 일’에 추론을 통해 알 수 있는 무관하지 않은 내용 및 앞 내용의 반복 } \\
\text { 예: 배우자 사정, 집안 사정 등 }\end{array}$ \\
\hline 1 & $\begin{array}{l}\text { 주제와 전혀 관련 없는 내용 } \\
\text { 예: 본인 이야기, 질문 다시 반복 }\end{array}$ \\
\hline
\end{tabular}

횡단보도 그림 설명하기

\begin{tabular}{|c|l|}
\hline 4 & $\begin{array}{l}\text { 주체와 행위를 모두 포함하면서 그림을 오류 없이 정확하게 설명 } \\
\text { 예: "아이들이 손 들고 가고", "여자(아줌마, 아가씨)가 양산 쓰고 가고", "목발을 짚은 여자가 서 있고", 교통 순경이 교통 정 } \\
\text { 리하고" 등 }\end{array}$ \\
\hline 3 & $\begin{array}{l}\text { 그림을 설명하는 내용이지만, 오류가 있는 경우 } \\
\text { 예: 양산 } \rightarrow \text { 우산, 목발 } \rightarrow \text { 지팡이 } \\
\text { 그림 대상의 설명을 일부분만 언급(주체가 빠지거나 행위가 빠짐) } \\
\text { 예: “손 들고 가고", "우산 쓰고" 등 }\end{array}$ \\
\hline 2 & $\begin{array}{l}\text { 그림을 설명하는 중에 주관적 의견 포함하는 내용/앞 내용의 반복 } \\
\text { 예: 위험해 보임, 좌측통행, 신호등을 잘 지켜야 된다 등 }\end{array}$ \\
\hline 1 & 질문 반복, 그림과 무관한 내용 \\
\hline
\end{tabular}

